\title{
発泡アルミニウムを用いた衝突エネルギー吸収体の圧縮特性*
}

\author{
橋 村 徹*1, M. Fauzan ADZIMAN ${ }^{* 2}$, 岸本 喜久雄*3
}

\section{Consideration of Impact Energy Absorption of Foamed Aluminum}

\author{
Tohru HASHIMURA*4, M. Fauzan ADZIMAN and Kikuo KISHIMOTO \\ ${ }^{* 4}$ Kobe Steel, Ltd., Aluminum \& Copper Div., Technical Department, \\ 1-5-5 Takatsukadai, Nishi-ku, Kobe-shi, Hyogo, 651-2271 Japan
}

\begin{abstract}
Foamed aluminum has unique impact energy absorption characteristic. In rate years, use to safety members of machinery for transportation such as a car, a train or a aircraft, foamed aluminum has been examined to make use of the lightweight and unique compression plastic deformation characteristics. To use foamed aluminum as safety member, it is necessary to make the member length large to get enough energy absorption. When foamed aluminum is used in the state of the long column instead of a short pillar, it seems that the problem of the outbreak of plastic instability and the compression buckling at the deformation progress could not be avoided. In this paper, basic plastic deformation characteristics of foamed aluminum in short and long column members are investigated. As a result of the examinations, an analytical model of foamed aluminum has proposed to understand and forecast the influence of material uniformity, aspect ratio, piled-up effects. Based on those results, actual sized examination bodies have produced and tested, and reliability of the model was confirmed.
\end{abstract}

Key Words: Foamed Aluminum, Nonferrous Metal, Energy Absorber, Buckling, Plastic Instability, Impact Strength, Safety, Transportation

\section{1. 粕咅}

発泡アルミニウムは, 金属系の発泡体としては初期 に工業化がなされたもののひとつである．独立気泡の 集合体よりなるセル構造をもち, 軽量で, 耐熱性, 断 熱性, 電磁波シールド性, 耐衝撃性, 意匠性, 加工性 など，さまざまな特徴のある特性をもっている(1)。 れらの特性を利用して, 軽量積層板, 電磁波遮蔽材, 吸音材として使用され，あるいは意匠材として内装建 材にも実用化されている(2).一部ではサンドイッチパ ネル材に加工して自動車構造にも実用化が検討されて いる(3).

最近では，その軽量性と独特な圧縮変形特性を活か して自動車,列車,航空機など輸送用機器のエネルギー 吸収部材への使用が検討されている. 発泡材の圧縮特 性については, 弾性率, プラトー応力に対する相対密 度の影響が大きいことなど多数の報告がなされている (4), (5). 一方, 発泡アルミニウムは圧縮降伏応力が比較 的低いため, 大きな運動エネルギーをもつ大型輸送用 機器の衝突安全部材として用いるためには, できるだ

* 原稿受付 2006 年 8 月 30 日.

*1 正員, (株) 神戸製鋼所 (丞 651-2271 神戸市西区高塚台 1-55).

*2 東京工業大学大学院理工学研究科( - 152-8552 東京都目黒 区大岡山 2-12-1)

*3 正員, フェロー, 東京工業大学大学院理工学研究科.

E-mail : t-hashimura@kobelco.jp
け圧壊ストロークを長くしてエネルギ一吸収体として の総吸収エネルギ一量を増すことが望まれる.しかし ながら弾性係数および塑性域の接線係数が一般金属よ りも桁違いに低いこと, 材料強度の不均一性や初期不 整の影響などにより，アスペクト比の大きな長柱領域 では圧縮時に不安定性が現れて座屈し, 大幅な吸収エ ネルギー能の低下をもたらす可能性がある. 発泡材の この様な圧縮時の不安定性についての検討はあまり行 われていないようである.

筆者らはこれまでに圧縮を受ける発泡アルミニウ ムの挙動を調べるためのマクロな F EM解析モデルを 作成し, 数值計算によりその静的圧縮挙動およひ動的 圧縮挙動を報告してきた ${ }^{(9)}$. 本報では, 発泡アルミ ニウムを大型輸送用機器の衝突安全部材として用いる 際に生じる塑性不安定性に着目し，これまでの検討に 新たに行った静的圧縮試験, 実大試験体の衝突試験結

Table 1 Basic properties of aluminum and foamed aluminum

\begin{tabular}{|c|c|c|c|c|c|c|}
\hline Material & $\begin{array}{c}\text { Cell size } \\
(\mathrm{mm})\end{array}$ & $\begin{array}{c}\text { Air } \\
\text { bubble } \\
\text { rate } \\
(\%) \\
\end{array}$ & $\begin{array}{c}\begin{array}{c}\text { Bulk } \\
\text { density }\end{array} \\
\left(\mathrm{g} / \mathrm{cm}^{3}\right)\end{array}$ & $\begin{array}{r}\text { Relativity } \\
\text { density }\end{array}$ & $\begin{array}{c}\text { Longitudinal } \\
\text { elastic } \\
\text { modulus } \\
(\mathrm{MPa}) \\
\end{array}$ & $\begin{array}{c}\begin{array}{c}\text { Yield } \\
\text { strength }\end{array} \\
(\mathrm{MPa}) \\
\end{array}$ \\
\hline $\begin{array}{l}\text { Foamed } \\
\text { aluminum }\end{array}$ & $2 \sim 7$ & $\fallingdotseq 90$ & $0.2 \sim 0.3$ & 0.09 & $30 \sim 50^{*}$ & $\doteqdot 2.1^{\#}$ \\
\hline $\begin{array}{c}\text { Pure aluminum } \\
(\mathrm{A} 1100-\mathrm{H} 12)\end{array}$ & - & - & 2.71 & - & 68600 & 105 \\
\hline $\begin{array}{c}\text { Aluminum } \\
\text { alloy } \\
\text { (A6063-T5) }\end{array}$ & - & - & 2.69 & - & 70000 & 145 \\
\hline
\end{tabular}


果, および数值解析モデルを使った検討結果を追加し, アスペクト比や材料の不均一性が圧縮挙動に及ぼす影 響を検討した.

\section{2. 発泡アルミニウムの圧舵特性}

$2 \cdot 1$ 基本物性 試験に用いた発泡アルミニウム は水素化チタニウムを発泡材とした溶湯法で工業的に 量産 ${ }^{(1)}$ されたものである. その標淮的な密度や基本物 性を通常のアルミニウム合金材料と比較して表 1 に示 す. 後述する様に, 発泡率, 密度の不均一性が素材各 部でみられ，その強度特性に及ぼす影響は大きいが， 本報で用いた材料の平均的な密度は $0.2 \sim 0.3 \mathrm{~g} / \mathrm{cm}^{3}$ の 範囲である.

$2 \cdot 2$ 短柱単一材の圧縮特性 発泡アルミニウム の基本的な圧縮特性を調查するため, 静的圧縮試験を 実施した. 用いた試験体は, 発泡アルミニウムを幅 $(W) 100 \mathrm{x}$ 奥行 $(D) 100 \mathrm{x}$ 高さ $(L) 200 \mathrm{~mm}$ の直方体に切り出 したものであり, その平均密度は $0.28 \mathrm{~g} / \mathrm{cm}^{3}$ であった. 試験体をアムスラー型油圧万能試験機のテーブル上に 置き,上方から剛な厚鋼板を介して準静的に圧縮した. 得られた圧縮荷重一変位関係を図 1 に示寸.

短柱単一材の静的圧縮試験結果から, 本報告で用い た発泡アルミニウム材の圧縮特性には, (1)変形初期に 高い反力が発生せず, 塑性変形領域に入る, (2)塑性変 形領域における荷重の上下動が非常に小さく, 応力が ほぼ一定のプラトー段階となる, (3)一定の圧縮率を受 けた後, セルが緻密化し反力荷重が高くなる, いわゆ る底付き現象がみられるが，その段階に到るまでの塑 性プラトーのストロークが一般金属材料と較べて長い, (4)塑性変形領域では座屈が生じやすくなる傾向がみ られるが，試験した短柱試験体では多少の不安定性が 変形途中で観察されるものの, 部材全体的な座屈は生 じず，最終的にはほぼ真直に押し潰される，などが指 摘でき，エネルギー吸収材料として優れた特性を持っ

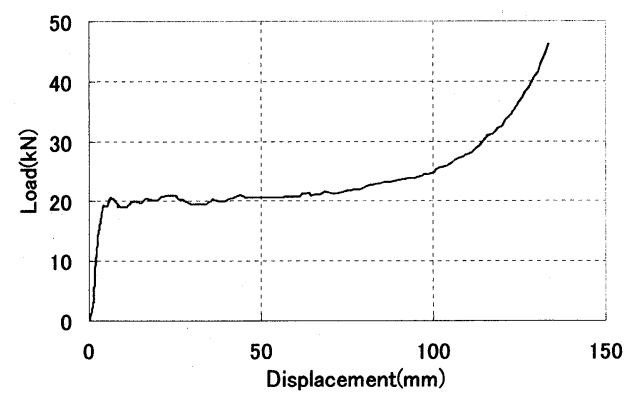

Fig.1 Static compression characteristics of short column $(W 100 \times D 100 \times 2200)$

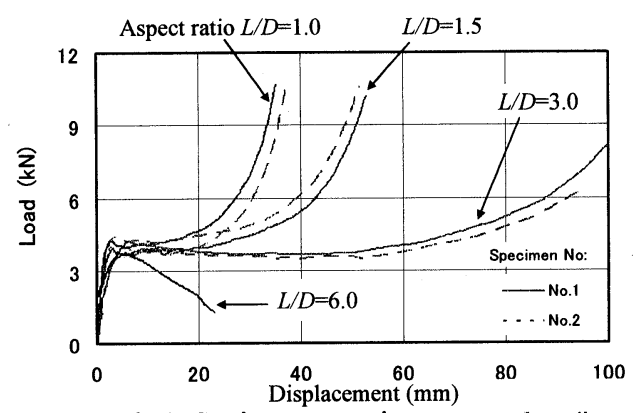

Fig.2 Static compression test results of long consecutive bodies
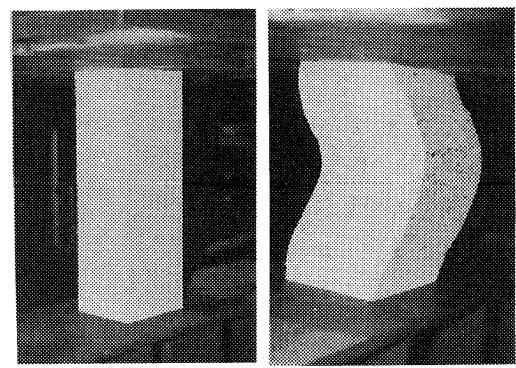

Fig.3 Example of static compression deformed-shape of long column, single unit body (Aspect ratio 3.0)

ていることがわかる。

\section{3. 長柱の静的圧綰試験}

$3 \cdot 1$ 長柱単一材の圧縮試験 次に,アスペクト比 の大きな材料を圧縮した場合の不安定性を調べる目的 で, 大型の発泡アルミニウム材から切り出した単一の 試験体を用い, 圧縮試験を行った. 形状は $50 \mathrm{~mm}$ 角の断 面を持つ直方体とし, アスペクト比を $1.0,1.5,3.0,6.0$ に変化させ, 短柱と同様な淮静的圧縮試験を行った. なお, 本試験体の平均密度は $0.24 \mathrm{~g} / \mathrm{cm}^{3}$ であるが, 個 体差があるため, 各 2 体の試験を行った. 得られた荷 重一変位関係を図 2 に, 試験前, 試験途中の変形状態 の例としてアスペクト比 3.0 の場合を図 3 に示す.

試験では, 同一条件の試験体でも発泡率・密度のば らつきのため降伏荷重, プラトー荷重に若干の個体差 が見られたが，全体的な変形挙動に大きな差は見られ なかった。変形状態の観察から,アスペクト比が 3 を 超える単一材が静的圧縮を受けると面外方向一の変形 が顕著に見られたが，アスペクト比が 3.0 の場合は, 一旦増加した面外変形が圧縮率の増加とともに次第に 抑制され，荷重低下を生じなかった，一方，アスペク 卜比が 6.0 の場合は, 図 3 にみられる様な面外一の屈 曲部を持った変形モ一ドが圧縮とともに大きくなり, 荷重が低下してエネルギ一吸收能が低下した，変形を 
詳細に観察すれば, 変形前には水平な層状であった各 繊維が複雑に屈曲した褶曲変形を生じており, 局部的 には高次の変形モードと言えるが, 全体変形は一次の 変形モードとなっている. この一次変形モードはアス ペクト比が大きいほど顕著に生じた.

面外変形を伴う裮曲変形モードの発生原因は, (1)材 料密度と強度の不均一性のため, 断面一様な圧縮が生 じないこと，(2)塑性域に入ると接線係数が低くなり座 屈変形が生じ易くなること，などが主な原因と考える ことができる.

\section{$3 \cdot 2$ 長柱積層材の圧縮特性 製造上の寸法制的} のため，大きな衝突エネルギーを吸収することのでき る, 大型でアスペクト比の大きな発泡アルミニウム部 材を単一の部材で製作するには限界がある。 また，部 材サイズが大きくなると製造上，発泡密度が通常より も不均一になり易く，均一な圧縮強度特性を得るのが 難しくなる．一方，小型の部材を積層することで大型 の部材を得ることは比較的容易であり, 均一な発泡率 も得られ易い.

ただし, 積層材の場合は圧縮時の不安定性が増し, エネルギー吸収能に影響を及ぼすことが懸念される. このため $W 600 \mathrm{~mm} \times 10400 \mathrm{~mm} \times 25250 \mathrm{~mm}$ の直方体ユニッ 卜を, 図 4, 5 に例示する様に $3 ， 4 ， 5$ 層に積層した積 層試験体の静的圧縮特性を調べた．単一材よりも大型 の直方体ユニットを用いた理由は, 後述する実大試験 に近いプロポーションの試験体を使って確認を行うた めである. 各ユニットの積層面には, ユニット同士の めり込み現象の緩和と,褶曲変形の抑制を図る目的で, $2 \mathrm{~mm}$ 厚のアルミニウム製仕切り板を配置した. なお, 仕切り板は各ユニットの間に挟むのみで接着などの固 定手段は用いていない.

得られた荷重一変位関係を図 6 に示す. 3,4 層試験

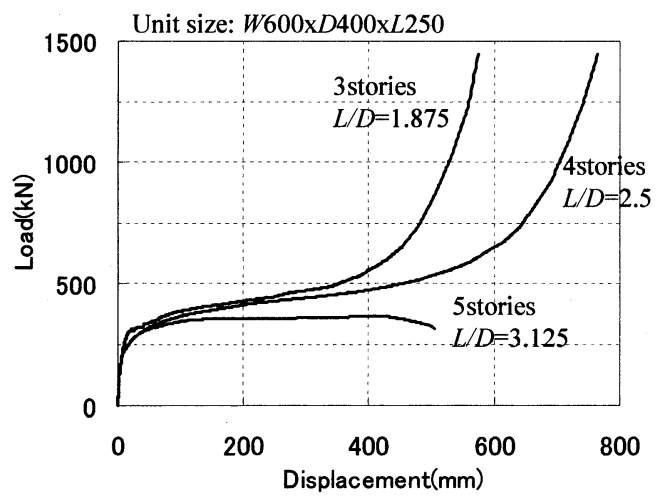

Fig.6 Static compression test results of piled-up long bodies(3-5 stories)

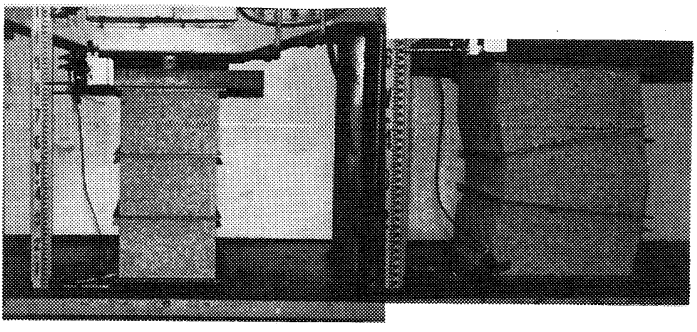

Fig.4 Before and after static compression test of 3 stories piled-up column (Aspect Ratio 1.875)
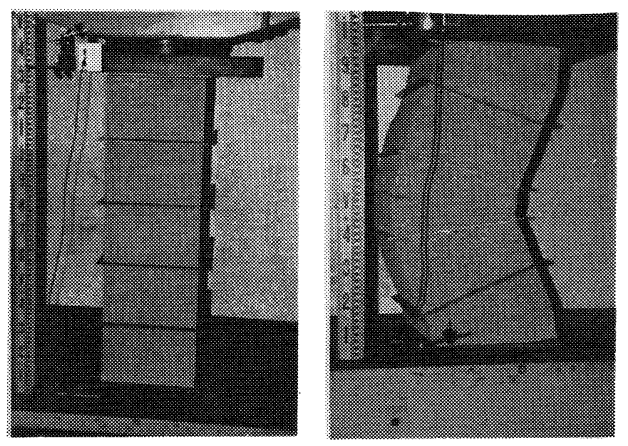

Fig.5 Before and after static compression test of 5 stories piled-up column (Aspect Ratio 3.125)

体では, 図 4 に示寸様な面外方向への褶曲変形が見ら れたものの，荷重が低下するような不安定性を生じる ことなく最終的には一様な緻密化により荷重が上昇し た. 一方， 5 層積層材では圧縮率の増大に従い褶曲変 形モードが次第に顕著となり, 圧縮率約 36\% で積層部 にずれが生じて荷重が低下しエネルギ一吸収能が奪わ れた. このように積層することにより圧縮ストローク の大きなエネルギー吸収体を得ることは可能であるが， 荷重低下を生じないためにはアスペクト比の制限が必 要である. 本試験の場合，5層試験体で変形途中の荷 重低下が生じたことから, 荷重低下を生じないための 限界アスペクト比は，2.5（積層 4 層）と 3.125 (同 5 層) の間と考えることができる. 小型の長柱単一材の 圧縮試験では, アスペクト比 3.0 まで荷重低下を生じ なかったことから, 積層材の限界アスペクト比は, 単 一材と同等かやや劣る程度と考えることができる.

\section{4. 有限要素法による圧缩挙動の解析}

$4 \cdot 1$ 解析方法 発泡アルミニウムの圧縮挙動に 及ぼす材料強度の不均一性, 積層効果, アスペクト比 の影響を調べること, および後述する大型部材の設計 のため, 静的および高速度領域での挙動を予測するこ とを目的とし, 有限要素法によるマクロな解析モデル 
を作成し数值シミュレーションを試みた. 数值解析に は陽解法解析コード LS-DYNA ver.960を用い, 発泡体 の圧縮変形特性を表現する物性モデルとして，3軸方 向の各応力成分が互いに連成しない直交異方性破壊モ デル(8)を用いた．まず短柱試験体の静的圧縮荷重一変 位関倸から材料の一軸圧縮時の応力一歪線図を求めた. 材料の弾性率は, 初期に $E_{o}$ であった弾性率が, 気泡が 潰れきるとアルミニウム素材の弾性率 $E_{a}$ まで上昇寸 るものとして, 相対体積 $V_{f}$, つまり変形後と変形前 の体積の比に応じて弾性率を線形に変化させる. すな わち,

$$
\begin{aligned}
& E=E_{o}+\beta\left(E_{a}-E_{o}\right) \\
& \text { ここに, } \\
& \beta=\left(1-V_{f}\right) /\left(1-V_{f c}\right), \\
& V_{f c} \text { : 気泡が完全圧壊する時の相対体積であり, } \\
& \text { 時をもって完全圧壊と仮定した. }
\end{aligned}
$$

$\left(1-V_{f}\right)$ は体積歪に等しいが，ポアソン比を 0 と仮定しているため, 体積歪と圧縮歪は等しくなる. また，応力と歪の各軸方向成分は互いに他軸成分に影 響せず，各軸独立に短柱試験から求めた応力一歪曲線 上を変化するが, 相対体積が $V_{f c}$ になると各軸成分が 関倸し弾完全塑性体として挙動する. 有限要素法解析 モデルを図 7 に示す. 解析対象を 3.1 節で述べた断面 $50 \mathrm{~mm}$ 角の長柱単一材，および同じ断面で高さ $50 \mathrm{~mm}$ の立方体の積層材の両者とし，試験と同様にアスペク 卜比を変化させた. 積層材の場合, 実験と同様に仕切 り板は固着せず, 各ユニットの間に接触を考慮して配 置した. ユニットと仕切板の摩擦係数は 0.6 とした. 静的試験と同じく下端を固定し，上端を一定速度で強 制変位させた. 静的解析の場合, 載荷速度は慣性力の 影響の小さい準静的な条件で行った.

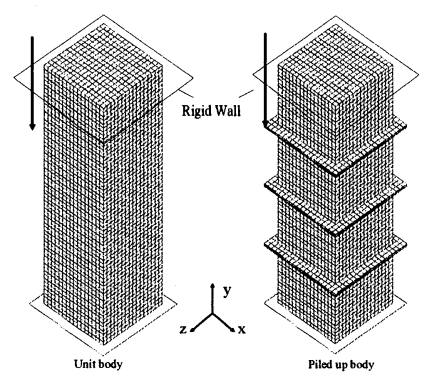

Fig.7 F.E.M. analyses model of long single unit and piled up bodies

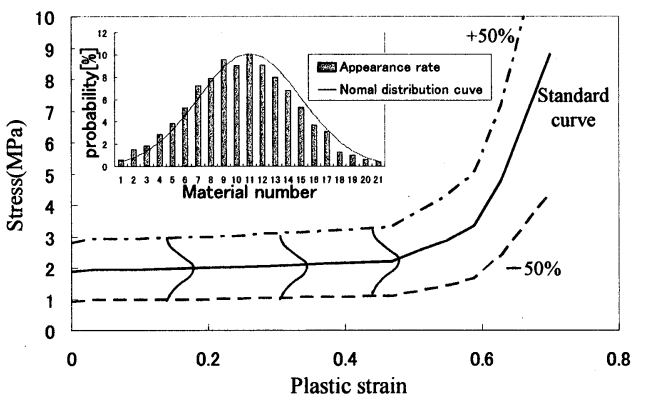

Fig.8 Stress-strain relation and distribution of material model
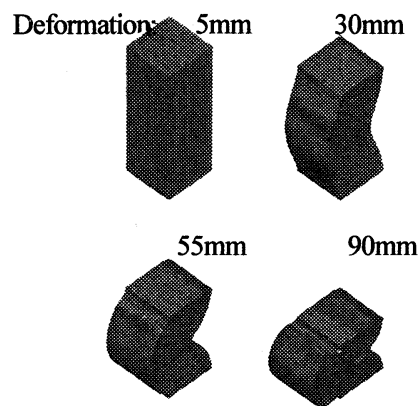

$90 \mathrm{~mm}$

Fig.9 Deformation behavior of analytical model (normal distributed strength of $\pm 50 \%$, single unit body, aspect ratio 3.0 )

$4 \cdot 2$ 材料強度分布のモデル化 用いた発泡アル ミニウムは, セルサイズが 2〜 7mm とばらつきのある 材料であり，強度，剛性が不均一である．このような 不均一性を考慮するため, 図 7 の有限要素法モデルに おいて, 要素毎の材料強度, 弾性率にばらつきを持た せたモデルを作成した. 図 1 から求めた標準的な応力 一歪曲線をもとに,この曲線にばらつきを与えるため, 図 8 にその概念を示寸ように標準強度を中心に $50 \%$ の範囲に 21 本の曲線を作成した. 各曲線の出現確率は 次の様にして決めた．まず，文献(5)で報告されている 発泡アルミニウムのセル壁サイズのばらつきデータか ら平均值 $m(2.68 \mathrm{~mm})$ と標準偏差 $\sigma(0.738 \mathrm{~mm})$ を求めた. ここで，セル壁サイズと材料強度，弾性率の間に負の 線形関係があり同様なばらつきで正規分布するものと 仮定し, セル壁サイズの分布曲線と分散係数 $\sigma / \mathrm{m}$ が同 じ值になるように材料強度の標準偏差 $\sigma(0.588 \mathrm{MPa})$ を 決め, 強度の分布を決めている，なお，強度分布の上 下限士50\%の範囲 $(1.068 \sim 3.204 \mathrm{MPa})$ は, 全体の約 $95 \%$ がその範囲に入ることになる標準偏差 $\sigma$ の \pm 2 倍の範 囲(0.960〜3.312MPa)にほぼ等しい. 弾性率のばらつき も同様にして求めた.

この様に定めた一つの材料強度・弾性率の組み合わ せを一つの材料番号に対応させ, 材料番号と解析要素 


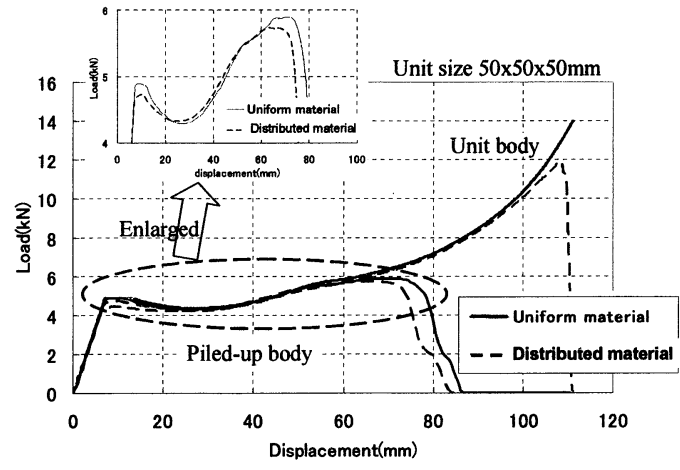

Fig.10 Load-deformation relation of analytical results

(Uniform and distributed strength material, 3 stories)

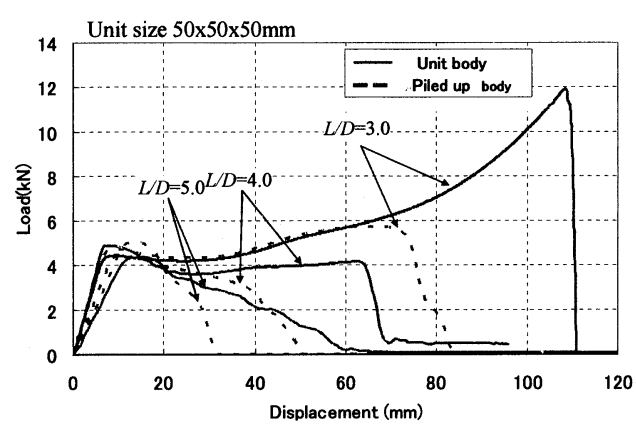

Fig.11 Load-deformation relation of analytical results (Normal distributed strength material)

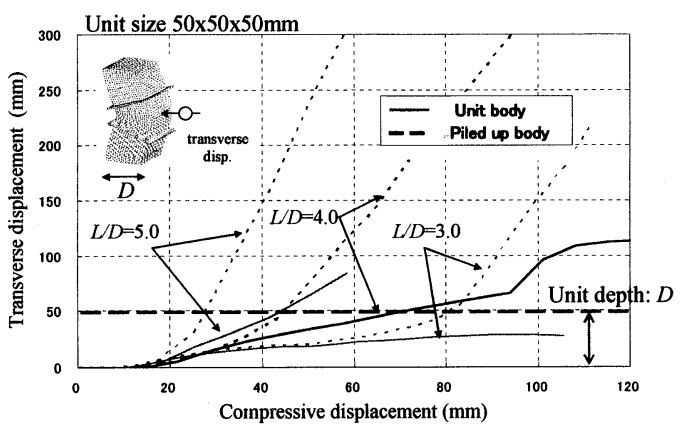

Fig.12 Transverse displacement of analytical results (Unit and piled-up bodies, $L / D=3.0-5.0$ )

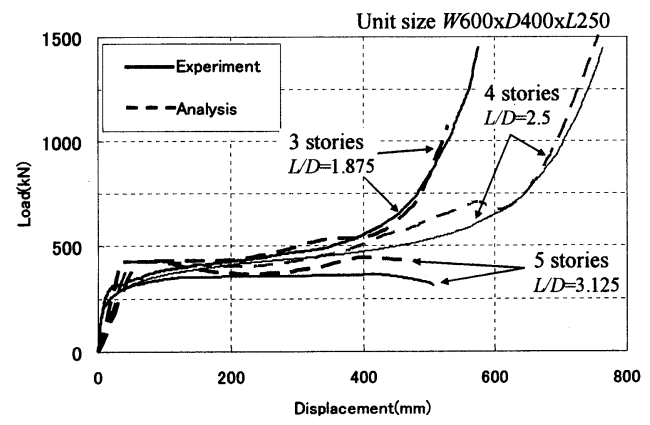

Fig.13 Load deformation relation of analytical results (Piled-up bodies, 3-5 stories)

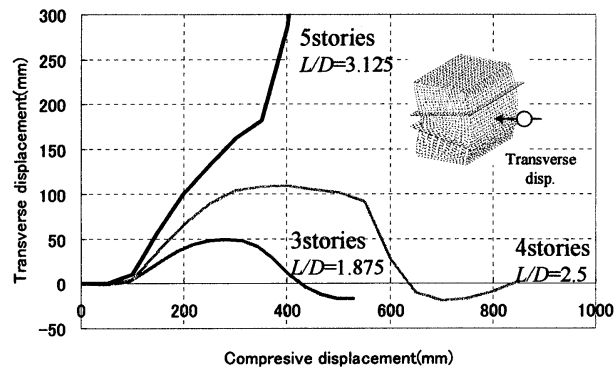

Fig.14 Transverse displacement of piled up bodies (Unit size W600xD400xL250, 3-5 stories)

との対応，すなわちモデル上の幾何的位置を乱数を使 いランダムになるよう配置した. また発泡アルミニウ 厶材料の歪速度依存性は比較的小さく無視しえる(9)も のと考え，モデル化には考慮していない.

$4 \cdot 3$ 解析結果 ${ }^{\star 5}$ 有限要素解析で得られたアス ペクト比 3.0 の単一材の変形状態の例を図 9 に示す. 図 3 の試験結果と同様に，圧縮とともに面外へのたわ みが増加し褶曲変形モードが顕著となる変形状態とな っている. 同じくアスペクト比 3.0 の単一材と積層材, およびその材料強度一様材と不均一材の圧縮荷重一変 位関係を比較して図 10 に示す.単一材に較べて積層材 は，荷重が早期に低下する傾向がみられる．これは積 層部分に負荷重が作用すると，各ユニット間が局部的 に離れる特性を持っており, 面外たわみ変形が進みや すいためと考えられる. また, 図 10 の荷重一変位関係 の拡大表示では, 材料強度を分布させた場合, 初期ピ 一ク強度は強度が一様な材料よりも小さいが，変形が 進行すると一様強度材よりも一旦強度が高くなり，そ の後再び一様強度材よりも荷重が低くなっている.こ れは, 強度の不均一があると強度の低い部分が先に塑 性変形を始めるため, 一様材より不均一材の方が初期 ピーク荷重が低くなるが, その後, 高強度部分も潰れ 始めるため荷重が一様材と同等，もしくは上回るもの と考えることができる

次に, 単一材と積層材のアスペクト比 $L / D$ を 3.0 か ら 5.0 まで変化させた場合の荷重一圧縮変位関係を図 11 に, 部材中央の面外たわみと圧縮変位の関係を図 12

$*_{5}$ 本解析では陽解法解析コードを用いているため, 材料の不 均一性など初期不整が全く無い場合でも, 繸圧縮時には数值 解析誤差に起因すると考えられる, 多少の面外二の座屈変形 が生じる.これは陰解法コードの結果と異なる現象であるが, 誤差に起因するためその変形量は比較的小さい. $4 \cdot 3$ 節で材料 強度の一様, 不均一など初期不整の大小と面外変形モ一ド発 生の程度を論じているが，それに影響を与える程度ではない。 


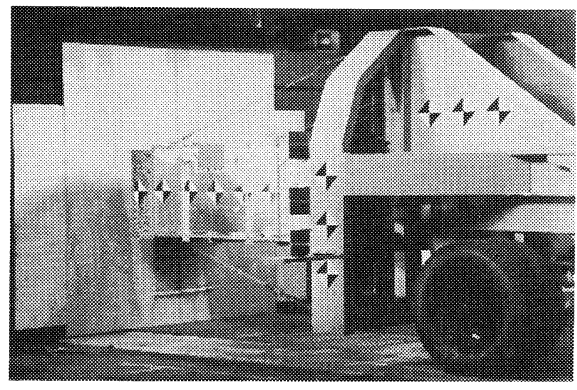

Fig.15 Actual sized examination set-up before impact

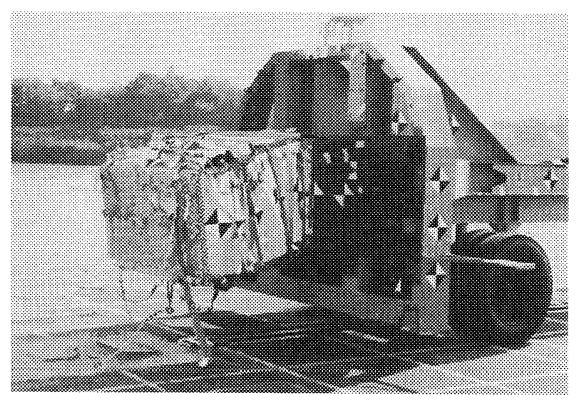

Fig.16 Test set-up after experiment (impact velocity $70 \mathrm{~km} / \mathrm{h}$ )
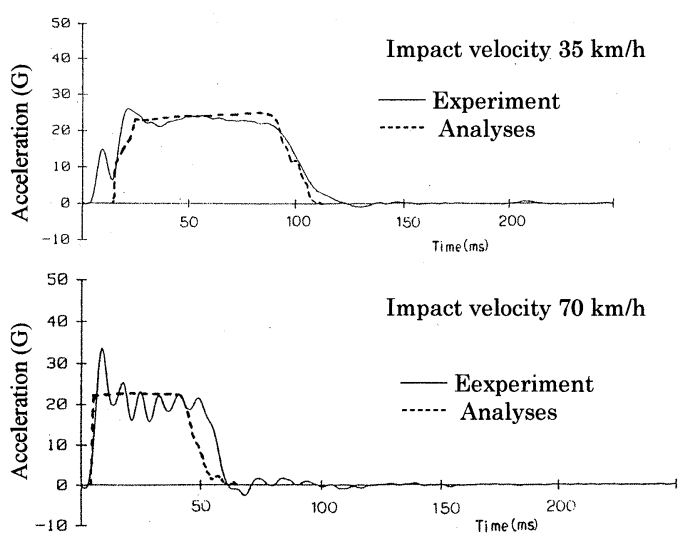

Fig.17 Acceleration curve of actual sized impact test

に示した. 図 11 から, $L / D=3.0$ の単一材以外は載荷途 中で荷重が低下するが，アスペクト比が大きいほど早 期に低下寸る傾向がわかる. また同じアスペクト比な らば, 積層材の方がより早期に荷重低下寸る. 一方, 図 12 では $L D=3.0$ の単一材は一度增加した面外たわみ が圧縮率の増加と共に次第に小さくなって安定化に向 かう傾向がみられるが，それ以外のケースは圧縮率の 増加と共に単調に面外たわみが増加している. また, 単一材よりも積層材の方が早期に面外たわみが増加し
ている. 特に部材奥行き寸法 D に相当する $50 \mathrm{~mm}$ 以上 に面外たわみが増加すると, その後は増加率が増して いるが, その際の圧縮変位は図 11 の荷重低下時の変位 とほぼ一致しており, 面外たわみの増加が荷重低下と 対応していることが理解できる.

$4 \cdot 4$ 長柱積層材の圧縮挙動の予測 前述の有限 要素法を用いた解析手法と考察の妥当性を確認するた め，同じ手法を用いて 3·2 節で述べた長柱積層試験体 と同一形状部材の圧縮変形特性を調べた. 得られた荷 重一変形関係を図 13 に試験結果と比較して示す.試験 結果と解析結果は概ね良好に一致している. また図 14 に示寸解析による圧縮変位と面外たわみの相関図から, 3 層, 4 層の積層材が圧縮を受けると一旦たわみ量が増 加して面外変形モードが発生するが, 変形が進むと次 第に面外たわみが減少し，この変形モードが抑制され ていることがわかる. 一方, 5 層積層材はたわみ量が 単調に増加し, 面外変形モードが顕著になって崩壊に 到る様子がわかる. 崩壊に到る限界のアスペクト比も 試験と同様な結果になっており, 用いたマクロ解析モ デルの結果は概ね妥当であると言える. 検討した積層 材の結果から, 安定な特性を保つための上限は, 4 な

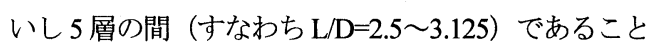
が予想される.

\section{5. 実大試験体の鼻突試験}

$5 \cdot 1$ 実大試験体と試験計測方法 発泡アルミニ ウムの静的圧縮挙動の検討結果から, 実大試験体の形 状を設計, 試作してエネルギー吸収性能の確認を行っ た. 試験体の断面は目的とするエネルギ一吸収体と同 寸で $W 1500 \mathrm{x} D 750 \mathrm{~mm}$ とし, 静的試験における考察結果 からアスペクト比約 0.9 の発泡アルミニウムを 3 層に 積層して全長 $L$ は $2025 \mathrm{~mm}$, すなわち短辺長 $D$ と全長 Lのアスペクト比を 3.0 より小さい 2.7 として計画した. 各段の間には仕切板（アルミニウム板, 板厚 $3 \mathrm{~mm}$ ）を 設けた. 用いた材料は平均密度が $0.27 \mathrm{~g} / \mathrm{cm}^{3}$ であった. 図 15 に実大試験体の外観を示す.試験体外面は金属製 薄板カバーで覆われているが, 変形拘束は行っていな い. 衝突試験は, 試験体を台車（総質量 $10,000 \mathrm{~kg}$ ) の 前面に固定し, 実車衝突試験場において牽引走行させ てコンクリート製バリヤに衝突させて行った. 計画段 階での吸収体の設計衝突速度は最大 $140 \mathrm{~km} / \mathrm{h}$ であっ たが, バリアに与えるダメージの限界を考慮し, 衝突 速度を低速 $35 \mathrm{~km} / \mathrm{h}$, 高速 $70 \mathrm{~km} / \mathrm{h}$ の 2 種類とした. 計 測は衝突速度と台車重心位置の加速度を計測し, SAE$\mathrm{J} 211^{(10)}$ に準じてチャンネルクラス 60 (カットオフ周 波数 $100 \mathrm{~Hz}$ ）のフィルタリングを行っている. 得られ 
た加速度波形に台車質量を乗じることにより衝突試験 体に加わる荷重波形とみなした。

\section{$5 \cdot 2$ 衝突試験および解析結果 衝突後の試験体} の状況を図 16 に示す.いずれの試験においても台車の 持つ運動エネルギーがほぼ完全に試験体に吸収された。 発泡アルミニウム試験体の変形モードには少し褶曲変 形モードの発生が見られるものの，大きな面外変形は 生じておらず，主に衝突方向に圧縮変形を生じたもの と判断される（試験体を上方から支持していたワイヤ ロープが外れているため, 図 16 では試験体がやや下方 に下がっている）．衝突試験で得られた台車重心の加 速度一時閒関係を図 17 に示す.試験体は衝突中に繸方 向に圧壊を続け，多少の加速度の上下動を生じながら もほぼ一定の反力を生じたのち, 衝突速度 $35 \mathrm{~km} / \mathrm{h}$ で は衝突開始後約 $110 \mathrm{ms,}$ 同じく $70 \mathrm{~km} / \mathrm{h}$ では約 $60 \mathrm{~ms}$ で衝突エネルギーを吸収した。

この実大衝突試験を，4.章で述べた解析手法を用い て, 試験と同一の衝突条件で数值解析した. 解析から 得られた荷重一時間関係の結果を図 17 の試験波形に 重ねて示す. 衝突速度 $35 \mathrm{~km} / \mathrm{h}, 70 \mathrm{~km} / \mathrm{h}$ いずれの場合 も, 解析結果は試験結果と良く一致していることが判 る. 試験結果の方が加速度波形の乱れがやや大きが, これは計測で不可避な振動波形を，フィルター処理で 除けなかったことが主因と考えている.

解析結果が静的圧縮試験結果および実大衝突試験 結果によく一致することから，実大試験では行えなか った, より高速域における発泡アルミニウムの変形挙 動も本解析手法で予測出来るものと考えている.

\section{6. 結 言}

大型の輸送用機器に発泡アルミニウムを衝突エネル ギー緩衝材として用いるため, 溶湯法で製作された発 泡アルミニウム長柱の圧壊不安定性に及ぼすアスペク 卜比, 材料の不均一性の影響, および単一材と積層材 の差異について試験および有限要素解析を用いて検討 し，以下の知見を得た.

1）発泡アルミニウム長柱が圧縮荷重を受けると塑性 不安定性を示し, 面外座屈モードが発生するため, 短 柱でみられる圧縮率に到る前に荷重が低下しエネルギ 一吸収量が低下する. 座屈変形はアスペクト比が大き いほど顕著に発生する. 単一の立方体試験材を用いて 行った試験では, アスペクト比 3.0 まで顕著な荷重低 下を生じない。

2) 大型試験体を得るため, アスペクト比が 1 以下の 発泡体を積層した試験体を作成した. 積層材の圧縮特 性は単一材と同等もしくはやや荷重低下が早くなる程
度である. 荷重低下が生じ始めるアスペクト比 $\mathrm{L} / \mathrm{D}$ は, $2.5<L D \leqq 3.125$ であり, 積層材では少なくともアスペ クト比が 2.5 程度以下であれば, エネルギー吸収特性 に影響を与えるような塑性不安定性は示さない．

3）有限要素法によるマクロ解析モデルを使って, 圧 縮時の挙動を検討した. 要素の材料強度, 弾性率に不 均一性を持たせて解析すれば，試験で得られた褶曲座 屈モードの発生, 荷重低下などの不安定現象や積層材 の変形挙動を追跡することができる.

4）静的試験での検討およびマクロ解析モデルでの検 討結果からアスペクト比に制限を設けて実大衝突試験 体を製作し，衝突エネルギー吸収特性を確認した。 マ クロ解析モデルと試験の荷重一時間関係がほぼ一致す るなど, 解析モデルの有効性を確認した. 試験が行え なかった, より高速度領域の変形挙動も本手法で予測 できるものと思われる.

\section{辞}

試験材の製作，試験実施に全面的にご協力頂いた神 鋼鋼線工業(侏)，伊藤雅夫氏（元神鋼鋼線工業），笠井 経民氏(神鋼鋼線工業)に謝意を表します。

\section{参考文献}

(1) Itoh, M., et. al., Development of foamed aluminum "ALPORAS" (in Japanese), Journal of Japan Institute of Metals, Vol. 26, No.4 (1987), pp.311-313.

(2) Ishii, E., et. al., Production Process and Application of Foamed Aluminum ALPORAS for Noise Control (in Japanese), R\&D Kobe Steel Engineering Reports, Vol.41, No.2 (1991), pp. 59-62.

(3) Emmelmann, Bunsman, Seeliger, Baumeister, complex shaped aluminum sandwich panel with aluminumfoam inside, Proceedings IBEC '97 Stuttgart (1997).

(4) Gibson, L.J., Ashby, M.F., Cellular Solids, (1988), p.175, p.187, Pergamon Press.

(5) Miyoshi, T., et. al., Enhancement of energy absorption in a closed-cell Aluminum by the modification of cellular structures, Scripta Materialia, Vol.41, No.10 (1999), pp.1055-1060.

(6) Hashimura, T., Itoh, M., F.E.M. Analyses of Foamed Aluminum Subjected to High Velocity Compression (in Japanese), Proceeding of the $48^{\text {th }}$ Japanese Joint Conference for the Technology of Plasticity (1997), pp.265-266. 
(7) Adziman,M.F.,et.al., The effects of inhomogeneity on the buckling behavior of metal foams, $4^{\text {th }}$ International Conference on Porous Metals and metal foaming technology, poster session (2005).

(8) J.O.Hallquist, LS-DYNA Theoretical Manual, (1994), p.16.34, Livermore Software Technology Corp.
(9) Hall,I.W.,Guden,M.,Yu,C.-J., Crushing of aluminum closed cell foams: Density and strain rate effects, Scripta Materialia., No.43, (2000), pp.515-521.

(10) SAE J211 OCT88 Recommended Practice, Instrumentation for impact test (1988), Society of Automotive Engineers, Inc. 